\title{
STATUS AND WASTE TREATMENT TECHNOLOGY IN KHAC NIEM RICE NOODLE VILLAGE, BAC NINH PROVINCE
}

\author{
Pham Thi To Oanh \\ Vietnam Cooperative Alliance
}

\section{ABSTRACT}

Khac Niem rice noodle village in Bac Ninh province operates spontaneously with small-scale, backward, manual production equipment, narrow production ground, therefore environmental pollution in this village has reached an alarming level, seriously affecting on the environment and community health. Waste water for producing noodle has the pollution concentration exceeding the permitted standard many times, especially BOD, COD, SS, Nitrogen, phosphorus and pathogenic microorganisms.... Methods are used such as: survey method, statistics, analysis and synthesis, expert method, method of laboratory analysis. $\mathrm{pH}$ is in the range of 5.1-7; DO is from 1.3 to $3.2 \mathrm{mg} / \mathrm{l} ; \mathrm{BOD}_{5}$ exceed the permitted standards $1.57-4.31$ times and SS 4.6 times and coliforms 4.2-4.4 times. Distributed waste water treatment system is a new solution for organic wastewater treatment with scale of less than $1000 \mathrm{~m}^{3} /$ day and night, with the advantage of high treatment efficiency, adapting to fluctuations in flow, no power consumption is required if the treatment area is at an appropriate slope, environmentally friendly treatment technology, waste water is treated by microorganisms in the waste water or through natural processes without chemicals and especially require simple operation and maintenance and at a very low cost.

Key words: waste water; rice noodle production; traditional village; Khac Niem; Bac Ninh.

Ngày nhận bài: 25/02/2020; Ngày hoàn thiện: 29/02/2020; Ngày đăng: 29/02/2020

\section{THỰC TRẠNG VÀ CÔNG NGHỆ XỬ LÝ RÁC THẢI TẠI LÀNG MỲ GẠO KHẮC NIẸM, TỈNH BẮC NINH}

\author{
Phạm Thị Tố Oanh \\ Liên minh Hợp tác xã Việt Nam
}

\section{TÓM TẮT}

Làng mỳ Khắc Niệm ở tỉnh Bắc Ninh hoạt động tự phát với quy mô nhỏ, lạc hậu, thiết bị sản xuất thủ công, mặt bằng sản xuất hẹp, do đó ô nhiễm môi trường ở làng này đã đến mức báo động, ảnh hưởng nghiêm trọng đến môi trường và sức khỏe cộng đồng. Nước thải để sản xuất mì có nồng độ ô nhiễm vượt quá tiêu chuẩn cho phép nhiều lần, đặc biệt là $\mathrm{BOD}, \mathrm{COD}, \mathrm{SS}$, Nitơ, phốt pho và vi sinh vật gây bệnh .... Phương pháp được sử dụng như: phương pháp khảo sát, thống kê, phân tích và tổng hợp, phương pháp chuyên gia, phương pháp phân tích phòng thí nghiệm. $\mathrm{pH}$ nằm trong khoảng $5,1-7$; DO là từ 1,3 đến $3,2 \mathrm{mg} / 1 ; \mathrm{BOD} 5$ vượt quá tiêu chuẩn cho phép 1,57-4,31 lần và SS 4,6 lần và coliforms 4,2-4,4 lần. Hệ thống xử lý nước thải phân tán là một giải pháp mới cho xử lý nước thải hữu cơ với quy mô dưới $1000 \mathrm{~m}^{3} /$ ngày và đêm, với ưu điểm là hiệu quả xử lý cao, thích ứng với biến động của dòng chảy, không cần tiêu thụ điện nếu khu vực xử lý ở độ dốc thích hợp, công nghệ xử lý thân thiện với môi trường, nước thải được xử lý bởi các vi sinh vật trong nước thải hoặc thông qua các quá trình tự nhiên không có hóa chất và đặc biệt yêu cầu vận hành và bảo trì đơn giản và với chi phí rất thấp.

Từ khóa: nuớc thải; sản xuất phở; làng truyền thống; Khắc Niệm; Bắc Ninh.

Received: 25/02/2020; Revised: 29/02/2020; Published: 29/02/2020

Email: oanhphamto@gmail.com

\section{https://doi.org/10.34238/tnu-jst.2020.02.2714}




\section{Introduction}

The traditional villages in our country are often spontaneous, small-scale, backward and manual production equipment, narrow production ground, and low awareness of environmental protection. From the above limitations, the environmental pollution in these villages has reached an alarming level, seriously affecting on the living environment and health of the people [1].

The country has more than 1,300 recognized traditional villages and 3,200 handicraft villages. However, these villages are unevenly distributed among regions. Up to $60 \%$ of traditional villages are concentrated in the northern region, mainly in provinces and cities such as Hanoi, Bac Ninh, Hung Yen, Thai Binh and Nam Dinh; the central region accounts for about $23.6 \%$ and the southern region accounts for about $16.6 \%$ of the craft villages. The traditional villages mainly focus on fields such as handicrafts, food processing; animal raising and slaughtering; weaving, dyeing and tanning; construction materials; scrap recycling... [2]. Due to mass development, lack of planning of many villages in rural areas, along with the unbalanced development between production needs and the ability of facilities; At the same time, the management is quite lax by the authorities in environmental management in this area, leading to serious environmental pollution.

In Vietnamese cuisine, rice noodle is a round, soft white fiber food, made from nonglutinous rice starch, made through the mold and boiled in water. It is a raw material, the main ingredient for processing many dishes, the name of the dish often has the word "rice noodle" (in Vietnamese "bun") such as bun ca, bun moc, bun cha, bun thang etc. Noodle is often used widely and diversified in combination with many other foods in the holidays, Tet, at parties and daily meals of the people, indispensable in some specialties of the Vietnamese people such as spring rolls, Hue beef noodles... [3].)

The way of rice noodle production is still local, lacking quality control and necessary food hygiene and safety. Particularly, there are places where the production and consumption of noodles are gathered into traditional villages such as Nghia My noodle village (Quang Ngai), Phu Do (Hanoi), Song Than (Binh Dinh), Khac Niem (Bac Ninh), etc. But all noodle making processes are still manual and can cause unsanitary. Method of micro biology technology in waste water technology is given in pilot study, aim at implementing in fact.

\section{Research method}

Object and scope of the research is waste water and production process in Khac Niem rice noodle village. Scope of research: Khac Niem rice noodle village, Bac Ninh. Conducting a survey of production households and local people with 204 detailed questionnaires, including 30 questions for selecting details of the production process, production status and environmental assessment. Moreover, analyzing and selecting domestic and foreign research results; statistical data, analysis into secondary information source and primary information source; laboratory analysis to polluted indicators $(\mathrm{pH}, \mathrm{BOD} 5, \mathrm{COD}, \mathrm{SS}, \mathrm{N}$, $\mathrm{P}, \ldots)$, to pilot of micro biology technology in waste water technology in these village. Assessment of water pollution according to QCVN 40: 2011/BTNMT: National technical regulation on quality of industrial waste water.

Samples were taken at 3 locations of village: M1: Waste water after filtration and washing stage at Hoa Mai rice noodle production establishment; M2: Waste water in the main drainage ditch of Hung Lan household; M3: Sewage drainage in the neighborhood. Sampling time: november 2019, which is a period of strong production.

\section{Results and discussion}

\subsection{Production technology}




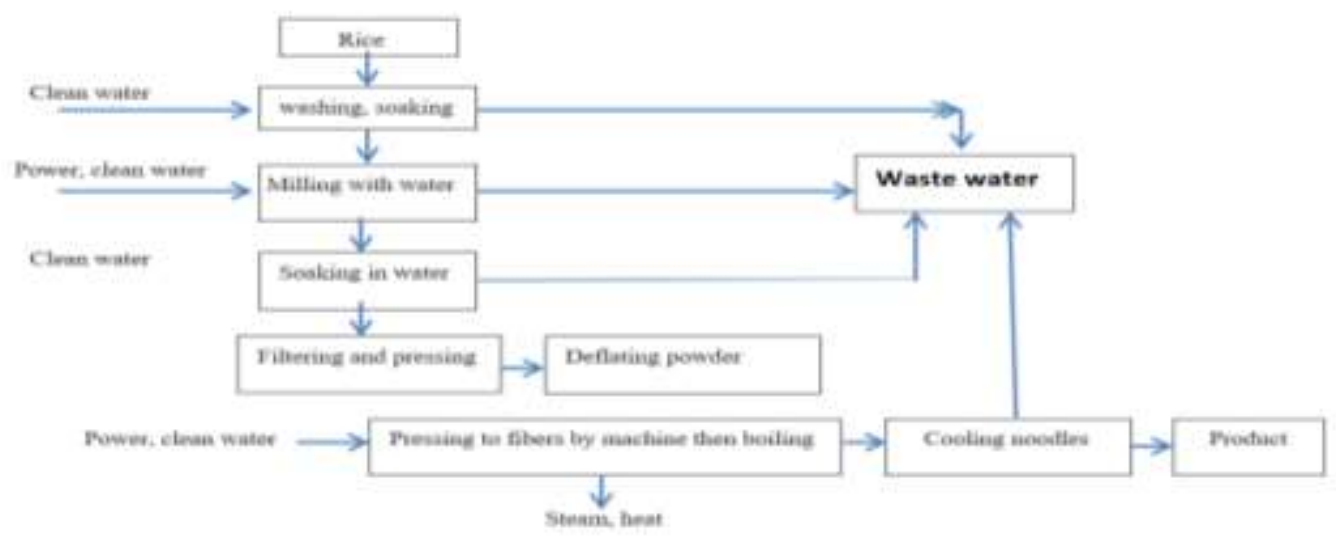

Figure 1. Rice Noodle production process

\subsection{Pollution situation of the traditional village}

Figure 1 shows rice noodle production process in Khac Niem village. Input of process are clean water, power. Output of process almost are waste water, a small part are steam, heat. Waste water are discharged out to environment.

Khac Niem rice noodle village is a longstanding traditional craft village specializing in producing famous rice noodles and rice cakes in Bac Ninh province. Currently, the whole commune has more than 300 households engaged in noodle production, mainly concentrated in Tien Trong, Tien Ngoai and Mo villages with an output of nearly 20,000 tons of noddles/year. However, corresponding to the large number of households in the village, the water pollution here is also alarming. Every day, about 3,000 cubic meters of untreated waste water is discharged directly into sewages and open ditches, causing serious pollution of the water environment.

At present, drainage canals running from Tien Ngoai to Mo village with a length of nearly $500 \mathrm{~m}$ and wide from 2 to $3 \mathrm{~m}$ have been seriously polluted and become a dead canal. The entire 7-kilometer section of the canal from Tien Trong village passing through 4 communes and discharging into Tao Khe river in Bac Ninh province has been seriously polluted by waste water from the Khac Niem rice noodle village and many livestock farms along the banks.

The process of producing noodles includes washing rice, soaking, milling, tempering the powder... Waste water quality in Khac Niem rice noodle village areas is shown in Table 1. The main pollution component is derived from starch. Waste water for producing noodle has the pollution concentration exceeding the permitted standard many times. $\mathrm{pH}$ of water: $\mathrm{pH}$ of analytical waste water is in the range of 5.1-7; A mild to neutral acid. Waste water contains excessive powder, during storage, transportation, musty growth and fermentation creating organic acids, causing low $\mathrm{pH}$. Low DO content is only from 1.3 to $3.2 \mathrm{mg} / \mathrm{l}$; Meanwhile, the best DO for aquatic organisms to grow is $>4 \mathrm{mg} / \mathrm{l}$, the DO for saturated water in fresh water at $30^{\circ} \mathrm{C}$ is $7.5 \mathrm{mg} / \mathrm{l} . \mathrm{BOD}_{5}$ content in the monitoring results all exceed the norm of 1.57-4.31 times. SS exceeds the permitted standards 4.6 times. Coliforms exceed the permitted standard 4.24.4 times.

Nutrients (N, P) with high concentrations cause eutrophication of water sources, algae growth reduces water quality. Microorganisms, esp. pathogenic bacteria and helminth eggs in water sources are special sources of pollution. Humans directly using contaminated water or infectious agents will transmit diseases such as dysentery, typhoid, polio, urinary tract infections, acute diarrhea, etc [4] [5]. 
Table 1. Waste water quality in Khac Niem rice noodle village areas

\begin{tabular}{|c|c|c|c|c|c|c|}
\hline \multirow{2}{*}{ No. } & \multirow{2}{*}{ Parameter } & \multirow{2}{*}{ Unit } & \multirow{2}{*}{ Standard QCVN 40:2011/BTNMT (B) } & \multicolumn{3}{|c|}{ Results } \\
\hline & & & & M1 & M2 & M3 \\
\hline 1 & $\mathrm{pH}$ & - & $5.5-9$ & 5.3 & 6.3 & 7 \\
\hline 2 & $\mathrm{DO}$ & $\mathrm{mg} / \mathrm{l}$ & - & 1.5 & 1.3 & 3.8 \\
\hline 3 & $\mathrm{BOD}_{5}\left(20^{\circ} \mathrm{C}\right)$ & $\mathrm{mg} / \mathrm{l}$ & 50 & 215.5 & 84.5 & 65.3 \\
\hline 4 & COD & $\mathrm{mg} / \mathrm{l}$ & 150 & 622.5 & 197.5 & 150.7 \\
\hline 5 & SS & $\mathrm{mg} / \mathrm{l}$ & 100 & 460.2 & 65.9 & 79.6 \\
\hline 6 & $\mathrm{NO}_{3}^{-}$ & $\mathrm{mg} / \mathrm{l}$ & - & 0.03 & 0.97 & 0.8 \\
\hline 7 & $\mathrm{NH}_{4}{ }^{+}$ & $\mathrm{mg} / \mathrm{l}$ & 10 & 0.925 & 2.002 & 1.235 \\
\hline 8 & $\mathrm{PO}_{4}^{3-}$ & $\mathrm{mg} / \mathrm{l}$ & - & $<0.5$ & $<0.5$ & $<0.5$ \\
\hline 9 & Coliform & MPN/100ml & 5000 & 21000 & 22000 & 11000 \\
\hline
\end{tabular}

Analysis and evaluation of practice proves that pollution are due to the densely populated village, lack of production ground, production workshops located inside the residential areas. On the other hand, under the pressure of population growth, ponds, lakes and rivers used to regulate the waste water are now leveled for housing. The number of remaining ponds and lakes is too small, leading to stagnant sewage, flooding into residential areas, causing serious pollution. In addition, the obsolete technology and production processes are also causes of pollution. The waste water treatment system only has a capacity of $450 \mathrm{~m}^{3} /$ day and night but it currently does not work because the daily discharge of waste water exceeds the prescribed capacity of about $2500 \mathrm{~m}^{3}$.

Table 2. Assessment of local people about the environment of Khac Niem rice noodle village

\begin{tabular}{|c|c|c|c|c|}
\hline No. & Information & Description & $\begin{array}{l}\text { Assessment } \\
\text { score }\end{array}$ & $\begin{array}{c}\text { Forecast of } \\
\text { environmental status }\end{array}$ \\
\hline & Ponds & $\begin{array}{l}\text { - Black color, much garbage } \\
\text { - Aquatic animals are difficult to } \\
\text { develop }\end{array}$ & 4 & $* * * *$ \\
\hline 2. & $\begin{array}{l}\text { Waste water } \\
\text { drainage system }\end{array}$ & Black color, much mud, bad smell & 4 & $* * * *$ \\
\hline 3. & Dug wells & $\begin{array}{l}\text { there is yellow residue, which may } \\
\text { be contaminated }\end{array}$ & 3 & $* * *$ \\
\hline 3. & Drilled wells & There is residue, sour smell & 3 & $* * *$ \\
\hline 4. & Air & $\begin{array}{l}\text { Is polluted by coal gas, the sour } \\
\text { smell from the process of soaking } \\
\text { rice }\end{array}$ & 2 & $* *$ \\
\hline 5. & Noise & $\begin{array}{l}\text { Noisy due to machinery operation } \\
\text { during production }\end{array}$ & 2 & $* *$ \\
\hline 6. & Waste & $\begin{array}{l}\text { A lot along roads (coal slag, } \\
\text { household waste, etc.) }\end{array}$ & 4 & $* * * *$ \\
\hline 7. & Paddy soil & $\begin{array}{l}\text { Pollution is not clearly confirm but } \\
\text { people think it is polluted. }\end{array}$ & 2 & $* *$ \\
\hline
\end{tabular}

Note: 4: Very serious; 3: Pretty serious; 2: Serious; 1: Less serious; 0: not serious

*****: The trend is very serious; ***: quite serious; **: serious; *: less serious

Survey results of interviewing local people shows that $87.2 \%$ of people rated the pollution at ponds and drainage systems are very serious with black color, much garbage, bad smell, aquatic animals are difficult to develop; $91.2 \%$ of people assessed that the water supply at natural wells and drilled wells was pretty polluted, with yellow residue and sour smell; $84.3 \%$ of people said that the air was seriously polluted by coal gas, the sour smell from the process of soaking rice, the noise; $88.6 \%$ of people rated the solid waste pollution very serious because of coal slag, household waste, etc. Assessment of local people about the environment of Khac Niem rice noodle village with assessment score (2-4), forecast of environmental status (*******) are shown in Table 2. 


\subsection{Microbiology technology in waste water treatment}

Because rice noodle is produced directly from rice with high starch content, BOD and COD concentrations are very high, so it is necessary to combine the use of both aerobic and anaerobic tanks to be thoroughly treated. Waste water of noodle production establishments under the collection system will go through trash rack to remove largesized solids such as packaging, plastic covers, leaves ... This process is aimed at protecting machinery and equipment for stable operation. After passing through trash rack, waste water will flow into sedimentation tank. Small-sized suspended solids will settle to the bottom of the tank and be recovered for animal feed. This stage has the effect of offloading the next biological processes. Waste water then flows to regulating tanks and with pumps, it is transferred to tanks for further treatment. In anaerobic biological tanks (UASB), anaerobic microorganisms will decompose organic matters in waste water into inorganic substances in simple form and Biogas $(\mathrm{CO} 2, \mathrm{CH} 4, \mathrm{H} 2 \mathrm{~S}, \mathrm{NH} 3$...), according to the following response:

Organic matters + Anaerobic microorganisms $\rightarrow \mathrm{CO}_{2}+\mathrm{CH}_{4}+\mathrm{H}_{2} \mathrm{~S}+$ New biomass $+\ldots$

In addition, the tank also installs the adhesive substrate system to increase the concentration of microorganisms in anaerobic biological tanks to accelerate the conversion of organic matters. After anaerobic biological tank, waste water is led through aerobic biological tank (Aerotank). In aerobic biological tank, aerobic microorganisms use dissolved oxygen to break down and convert organic matters in waste water into biomass, $\mathrm{CO}_{2}$ and water. The microorganisms form a group, in the form of activated sludge flakes. Dissolved oxygen source is supplied from air blower through air distribution pipe system. When the dissolved oxygen source is guaranteed, biological oxidation of pollutants and nitrification takes place thoroughly. As a result, the water is cleaned and the microbial biomass increases. After treatment with aerobic biological treatment, waste water will flow through sedimentation tank in order to separate microorganism biomass (biological mud) from the waste water stream. The clear water will go through the disinfection tank. The sediment deposited in the bottom of the tank will circulate back to the biological tank to maintain the mud concentration, the residual sediment will be periodically collected. In the disinfection tank, disinfectant chemicals will be pumped quantitatively into the tank to kill harmful microorganisms in the waste water, and oxidize the remaining organic substances in the water. Finally, the waste water is pumped into a pressure filtration device to remove the remaining residue that has not been carried out by the sedimentation process.

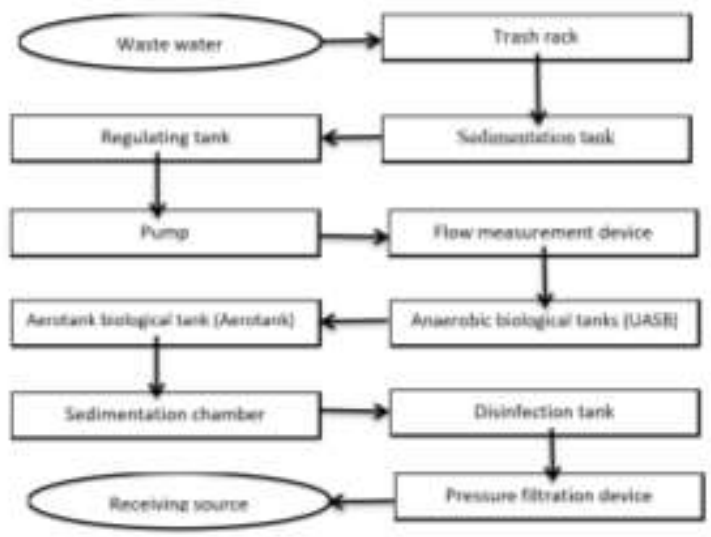

Figure 2. Waste water treatment processing lines for noodle production

Water after the treatment system of noodle production establishments is ensured at the level B - Vietnam Standard QCVN 40: 2011 / BTNMT, then it will be discharged into the receiving environment.

Distributed waste water treatment system is a new solution for organic waste water treatment with scale of less than $1000 \mathrm{~m}^{3} /$ day and night, with the advantage of high treatment efficiency, reliable, long-term and adaptive to fluctuations in flow, no power consumption is required if the treatment area 
has a suitable slope, environmentally friendly treatment technology, waste water treatment by microorganisms in the waste water or thanks to natural process without using chemicals and especially requires simple operation and maintenance and very low cost. Description of technology showed in figure 3.

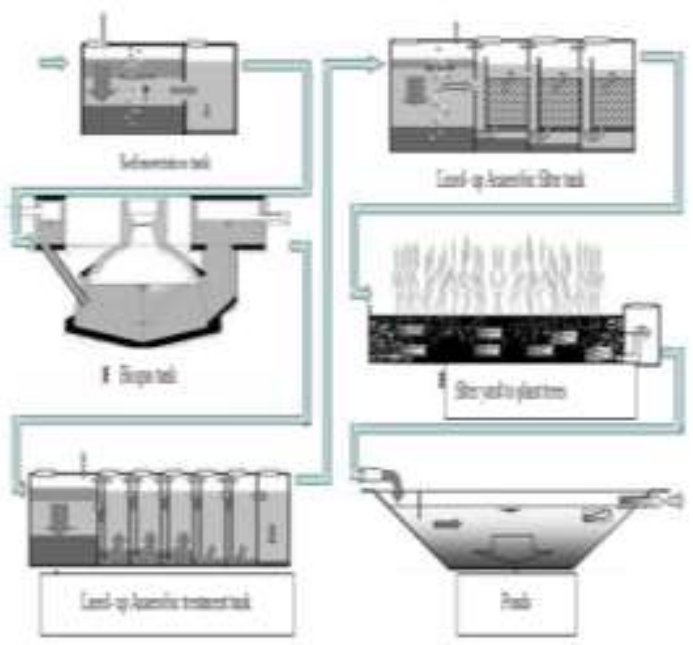

Figure 3. Waste water treatment with microbiological technology

Anaerobic filter tank model: Filter material: coal slag is the material selected during the research process. Model of anaerobic filter tank: the structure of anaerobic filter tank is a plastic tank with a capacity of $\mathrm{V}=50$ liters which is tightly sealed, containing filter material inside, under which there is a filter plate. The waste water flows into anaerobic filtration tank along the pipeline from the top of the high tank. Waste water after being filtered in anaerobic tanks will be transferred to biological rotating disc tanks along the pipeline at the bottom of the anaerobic tanks.

Model of biological rotating disc device: In biological rotating disks: large surface area and roughness so that microorganisms can stick during the decomposition of organic matters. In rotation shaft, the disks are mounted on a rotating shaft. In treatment tank, made of corrugated iron painted with anti-rust paint, with a capacity of 60 liters. Engine system consist of the motor used in the model is a geared motor. The belt drive system is used to reduce the speed to about 3 rpm (ratio of about 1: 5). Caculating of time effects on the concentration of pollutants after anaerobic treatment, with $\mathrm{v} 2=1$ liter $/ \mathrm{h}$ is shown in Table 3.

Table 3. Time effects on the concentration of pollutants after anaerobic treatment, with $v 2=1$ liter $/ \mathrm{h}$

\begin{tabular}{ccccccc}
\hline \multirow{2}{*}{$\begin{array}{c}\text { Treatment } \\
\text { time }(\mathbf{h})\end{array}$} & $\begin{array}{c}\text { COD } \\
(\mathbf{m g} / \mathbf{l})\end{array}$ & Efficiency $(\boldsymbol{\%})$ & $\begin{array}{c}{\left[\mathbf{N H}_{\mathbf{+}}{ }^{+}\right]} \\
(\mathbf{m g} / \mathbf{l})\end{array}$ & $\begin{array}{c}\mathbf{N H}^{+} \\
\mathbf{E f f i c i e n c y} \\
\mathbf{( \% )}\end{array}$ & $\begin{array}{c}\text { SS } \\
(\mathbf{m g} / \mathbf{l})\end{array}$ & $\begin{array}{c}\text { Efficiency } \\
(\boldsymbol{\%})\end{array}$ \\
\hline 0 & 5291.59 & 0.00 & 32.47 & 0.00 & 280 & 0 \\
2 & 4326.89 & 18.23 & 23.33 & 28.15 & 269 & 3.93 \\
4 & 3733.22 & 29.45 & 17.88 & 44.93 & 244 & 12.86 \\
6 & 3213.77 & 39.27 & 15.11 & 53.46 & 197 & 29.64 \\
8 & 3065.35 & 42.07 & 14.69 & 54.76 & 173.2 & 38.14 \\
16 & 1952.23 & 63.11 & 13.52 & 58.36 & 158.4 & 43.43 \\
24 & 1358.57 & 74.33 & 13.10 & 59.66 & 140 & 50 \\
\hline
\end{tabular}

Table 4. Time effects on the concentration of pollutants after anaerobic treatment, with $v 2=1.5$ liters $/ \mathrm{h}$

\begin{tabular}{ccccccc}
\hline \multirow{2}{*}{$\begin{array}{c}\text { Treatment } \\
\text { time (h) }\end{array}$} & $\begin{array}{c}\text { COD } \\
(\mathbf{m g} / \mathbf{l})\end{array}$ & $\begin{array}{c}\text { Efficiency } \\
(\boldsymbol{\%})\end{array}$ & $\begin{array}{c}{\left[\mathbf{N H} \mathbf{4}^{+}\right]} \\
(\mathbf{m g} / \mathbf{l})\end{array}$ & $\begin{array}{c}\mathbf{N H}_{\mathbf{4}} \mathbf{E f f i c i e n c y}_{(\boldsymbol{\%})} \\
\mathbf{n y y y y y y}\end{array}$ & $\begin{array}{c}\mathbf{S S} \\
(\mathbf{m g} / \mathbf{l})\end{array}$ & Efficiency $(\boldsymbol{\%})$ \\
\hline 0 & 5145.4 & 0.00 & 35.24 & 0.00 & 304 & 0 \\
2 & 4712.7 & 8.41 & 30.73 & 12.81 & 297 & 2.43 \\
4 & 4424.0 & 14.02 & 26.30 & 25.38 & 276 & 9.14 \\
6 & 3918.7 & 23.84 & 23.19 & 34.19 & 222 & 27.07 \\
8 & 3197.4 & 37.86 & 17.25 & 51.06 & 211 & 30.50 \\
16 & 2547.5 & 50.49 & 15.57 & 55.81 & 181 & 40.36 \\
24 & 1970.7 & 61.70 & 15.21 & 56.85 & 163 & 46.36 \\
\hline
\end{tabular}


Table 5. Time effects on the concentration of pollutants after anaerobic treatment, with $v 2=3$ liters $/ h$

\begin{tabular}{|c|c|c|c|c|c|c|}
\hline \multirow{2}{*}{$\begin{array}{c}\text { Treatment } \\
\text { time (h) }\end{array}$} & \multicolumn{2}{|c|}{ COD } & \multicolumn{2}{|c|}{$\mathrm{NH}_{4}{ }^{+}$} & \multicolumn{2}{|c|}{ SS } \\
\hline & $\begin{array}{c}\text { COD } \\
(\mathrm{mg} / \mathrm{l})\end{array}$ & $\begin{array}{c}\text { Efficiency } \\
(\%)\end{array}$ & $\begin{array}{c}{\left[\mathrm{NH}_{4}{ }^{+}\right]} \\
(\mathrm{mg} / \mathrm{l})\end{array}$ & $\begin{array}{c}\text { Efficiency } \\
(\%)\end{array}$ & $\begin{array}{c}\mathrm{SS} \\
(\mathrm{mg} / \mathrm{l})\end{array}$ & Efficiency (\%) \\
\hline 0 & 5236.8 & 0.00 & 30.46 & 0.00 & 295 & 0 \\
\hline 2 & 4943.0 & 5.61 & 27.26 & 10.50 & 292 & 1.07 \\
\hline 4 & 4649.2 & 11.22 & 23.55 & 22.67 & 274 & 7.14 \\
\hline 6 & 4061.7 & 22.44 & 20.70 & 32.03 & 258 & 12.50 \\
\hline 8 & 3621.2 & 30.85 & 17.41 & 42.84 & 252 & 14.57 \\
\hline 16 & 3180.3 & 39.27 & 14.38 & 52.79 & 193 & 34.57 \\
\hline 24 & 2519.4 & 51.89 & 13.43 & 55.90 & 170 & 42.50 \\
\hline
\end{tabular}

Caculating of time effects on the concentration of pollutants after anaerobic treatment, with v2 $=1.5$ liters $/ \mathrm{h}$ is shown in Table 4 .

Caculating of time effects on the concentration of pollutants after anaerobic treatment, with v2 $=3$ liters $/ \mathrm{h}$ is shown in Table 5 .

From the 3 tables above, it is shown that the more increasing the flow rate is, the less efficiency of the treatment of organic matters, the content of ammonium and suspended solids in noodle production waste water. And to ensure the efficiency of the filtration process, we should choose the flow rate of the tank is 1 liter/h. This method is very suitable for small businesses because of the low cost and quite high efficiency. It can be applied suitable for this village.

\section{Conclusions}

The Rice Noodle village of Khac Niem, Bac Ninh province is polluted with the parameters exceeding QCVN 40: 2011/BTNMT (B) including COD, DO, BOD5 and Coliform. The indicators $\mathrm{NO}_{3}{ }^{-}, \mathrm{NH}_{4}{ }^{+}, \mathrm{PO}_{4}{ }^{3-}$ are all of low value, this has not caused negative impacts on the environment due to the limited production scale. However, the level of pollution of organic substances is significant, but Khac Niem Noodle Village has no treatment system, which will adversely affect the environment and human health.

The application of microbial treatment technology line will reduce the concentration of BOD, COD, SS, etc. in the water, which helps minimize the sources of pollution, and it must be combined with measures to improve the polluted environment and propagated to improve people's awareness to prevent pollution. It can be applied suitable for this village.

\section{REFERENCES}

[1]. T. M. Ngo, D. T. Vu, and Q. L. Bui, Environmental planning for traditional villages. Natural Science and Technology Publishing House, Hanoi, Vietnam, 2017.

[2]. T. T. O. Pham, Community-based trade village environment management, 3-year project 2014 - 2016, Vietnam Cooperative Union, Ha Noi, Vietnam, 2016.

[3]. D. D. Le et al. (2007), "Innovating and improving the competitiveness of agriculture in international integration", Journal of Science and Technology, 47(132), pp. 135142, 2007.

[4]. V. C. Le, Integration system in waste water treatment technology - vol.1. Statistical Publishing House, Vietnam, 2014.

[5]. V. C. Le, Integration system in waste water treatment technology - vol. 2. Statistical Publishing House, Vietnam, 2015. 